\title{
Implementasai Pembelajaran Perilaku Pencegahan Penyalahgunaan Narkoba Dalam Pendidikan Jasmani
}

\author{
${ }^{1}$ Brio Alfatihah, ${ }^{2}$ Tarpan Suparman, ${ }^{3}$ Aang Solahudin Anwar \\ ${ }^{1}$ PJKR FKIP Universitas Majalengka \\ 2, 3PGSD FKIP Universitas Buana Perjuangan, Jl. HS.Ronggo Waluyo,Karawang, Jawa Barat \\ e-mail: 'brioalfatihah99@gmail.com, 2tarpan.suparman@ubpkarawang.ac.id, \\ 3aang.solahudin@ubpkarawang.ac.id
}

\section{Implementation of Learning Behavior of Drug Abuse Prevention in Physical Education}

\begin{tabular}{l}
\hline Kata Kunci \\
\hline Implementasi, $\quad$ Perilaku, \\
$\begin{array}{l}\text { Pencegahan Narkoba, } \\
\text { Pendidikan Jasmani. }\end{array}$
\end{tabular}

Abstrak

Indonesia darurat narkoba, ya kalimat ini yang menggambarkan kondisi Negara Replubik Indonesia pada saat ini. Hal ini diakibatkan maraknya peredaran dan penyalahgunaan narkoba. Di Indonesia, data dari BNN RI menunjukan pada tahun 2004 bahwa 15\% dari jumlah penduduk Indonesia terlibat penyalahgunaan narkoba (3,2 juta jiwa) dan pada tahun 2005menunjukan bahwa15.000 orang meninggal setiap tahun akibat narkoba (Badan Narkotika Provinsi DKI Jakarta, 2009). Data terakhir penyalahgunaan narkoba pada tahun 2014 mengalami peningkatan sebanyak 4 juta jiwa (BNN, 2015). Tidak menutup kemungkinan penyalahgunaan narkoba akan terus meningkat di tahuntahun berikutnya selama belum adanya penerapan penddikan akan bahaya narkoba di tingkat Sekolah Menengah Pendidikan dipercaya akan mengatasi masalah bangsa Indonesia agar terhindar dari penyalahgunaan narkoba. Keyakinan ini diperkuat karena pendidikan merupakan upaya yang direncanakan untuk mempengaruhi orang lain baik individu, kelompok, atau masyarakat sehingga mereka melakukan apa yang diharapkan oleh pelaku pendidikan (Notoatmodjo, 2003: 16). Selain itu dalam UU RI No. 20 Tahun 2003 tentang Sistem Pendidikan Nasional, pasal 1. Menjelaskan bahwa: "Pendidikan adalah meliputi segala sesuatu yang dikerjakan oleh seseorang untuk dirinya atau yang dikerjakan oleh orang lain untuk dia, dengan tujuan mendekatkan dia kepada tingkat kesempurnaan" Dari pendapat beberapa ahli dan berdasarkan Undang-Undang Sistem Pendidikan Nasional tersebut perilaku penyalahgunaan narkoba dapat diatasi. Sedangkan pendidikan yang dipilih oleh peneliti adalah Pendidikan Jasmani. Pertimbangan ini dipilih karena dalam Silabus pembelajaran di sekolah dalam mata pelajaran Pendidikan Jasmani ada beberapa materi mengenai penyalahgunaan narkoba itu sendiri. Selain pertimbangan sebelumnya, Pendidikan Jasmani tidak hanya bertujuan untuk mendorong pertumbuhan fisik saja, tetapi seperti yang dikemukakan oleh Freeman (2007: 27-28) bahwa pendidikan jasmani menggunakan aktivitas jasmani untuk menghasilkan peningkatan secara menyeluruh terhadap kualitas fisik, mental dan emosional peserta didik sebagai satu kesatuan yang utuh. Melalui pendidikan jasmani olahraga dan kesehatan ini diharapkan peserta didik menjadi "insan berpendidikan secara jasmani (physically educated person)" yang tidak hanya menekankan pada keterampilan motorik serta pola gerak tetapi dapat memelihara peningkatan kesehatan seperti yang dikemukakan oleh Metzler (2005: 14) seseorang dapat menjadi "insan berpendidikan secara jasmani (physically 
educated person)" harus memenuhi standar: (1) mendemonstrasikan kemampuan motorik dan keterampilan dan pola gerak yang diperlukan untuk menampilkan berbagai aktivitas fisik, (2) mendemonstrasikan pemahaman akan konsep gerak, prinsip-prinsip, strategi dan taktik sebagaimana yang mereka terapkan dalam pembelajaran dan kinerja berbagai aktivitas fisik, (3) berpartisipasi secara regular dalam aktivitas fisik, (4) mencapai dan memelihara peningkatan kesehatan dan derajat kebugaran, (5) menunjukkan tanggung jawab personal dan sosial berupa respek terhadap diri dan orang lain dalam suasana aktivitas fisik, dan (6) menghargai aktivitas fisik untuk kesehatan, kesenangan, tantangan, ekspresi diri, dan interaksi sosial. Oleh karena itu penulis mencoba meneliti mengimplementasikan program pencegahan perilaku penyalahgunaan narkoba dalam pendidikan jasmani. Sehingga pendidikan jasmani, olahraga dan kesehatan dapat menjadi salah satu cara atau pelindung untuk meningkatkan pengetahuan akan pentingnya mencegah penyalahgunaan narkoba

\section{Keywords:}

Implementation, Behavior,

Prevention, Education.

\section{Abstract:}

Indonesia is a drug emergency, yes, this sentence illustrates the current condition of the Indonesian Replubic State. This is caused by rampant drug trafficking and abuse. In Indonesia, data from the National Narcotics Agency of the Republic of Indonesia shows in 2004 that 15\% of Indonesia's population was involved in drug abuse (3.2 million) and in 2005 showed that 15,000 people died each year due to drugs (Jakarta Provincial Narcotics Agency, 2009). The latest data on drug abuse in 2014 has increased by 4 million (BNN, 2015). Do not rule out the possibility of drug abuse will continue to increase in the following years as long as there is no education on the dangers of drug education at the Secondary School level Education is believed to solve the problem of the Indonesian people in order to avoid drug abuse. This belief is strengthened because education is a planned effort to influence others, whether individuals, groups, or the community, so that they do what is expected by education practitioners (Notoatmodjo, 2003: 16). In addition, in RI Law No. 20 of 2003 concerning the National Education System, article 1. Explains that: "Education is everything that is done by someone for himself or done by someone else for him, with the aim of bringing him closer to the level of perfection" From the opinion of some experts and based on the Act -Chief The National Education System can overcome drug abuse behavior. While the education chosen by researchers is Physical Education. This consideration was chosen because in the Syllabus of learning in schools in Physical Education subjects there is some material regarding drug abuse itself. In addition to previous considerations, Physical Education not only aims to encourage physical growth, but as Freeman (2007: 27-28) states that physical education uses physical activity to produce overall improvements to the physical, mental and emotional quality of students as one complete unity. Through sports physical education and health it is expected that students become "physically educated people" who not only emphasize motor skills and movement patterns but can maintain health improvement as stated by Metzler (2005: 14) a person can become "Physically educated person" must meet the following standards: (1) demonstrate motor skills and the skills and patterns of motion needed to display various physical activities, (2) demonstrate an understanding of the concepts of motion, principles, strategies and tactics as they apply in learning and performance of various physical activities, (3) participate regularly in physical activities, (4) achieve and maintain improved health and fitness levels, (5) demonstrate personal and social responsibility in the form of respect for self and others in an atmosphere of activity s physical, and (6) values physical activity for health, pleasure, challenges, self-expression, and social interaction. Therefore the author tries to examine implementing a program to prevent drug abuse behavior in physical education. So physical education, sports and health can be one way or a protector to increase knowledge of the importance of preventing drug abuse 
Article History :

Received : 5 Januari 2019

Revised : 6 Februari 2019

Accepted : 10 Mei 2019

\section{Pendahuluan}

Indonesia darurat narkoba. Kalimat itu sepertinya cocok dan tepat digunakan saat ini. Masalah penyalahgunaan narkoba di kalangan remaja telah menerima banyak perhatian baik di literatur penelitian dan media publik. Dinas Kesehatan telah melihat pada catatan dalam menetapkan tujuan nasional yang spesifik di bidang pencegahan dan pengobatan (U.S. Dept. of Health and Human Services dalam Collingwood et.al, 1991: hlm. 74). Di Indonesia, penyalahgunaan narkoba (pengguna narkoba) mengalami peningkatan dari waktu kewaktu. Menurut data penelitian Badan Narkotika Nasional (BNN dalam Sriningsih, 2015: hlm. 44-45) memperkirakan jumlah pengguna narkoba di Indonesia akan terus meningkat. Tahun 2015, diprediksi angka prevalensi pengguna narkoba mencapai 5,1 juta orang. Menurut Deputi Pencegahan BNN Yapi Manate, jumlah angka kematian akibat penyalahgunaan narkoba cukup mengkawatirkan. Diperkirakan angka kematian tersebut mencapai 104.000 orang yang berumur 15 tahun dan 263.000 orang yang berumur 64 tahun. Mereka meninggal akibat mengalami overdosis. BNN juga menyebutkan bahwa sebanyak 53\% penduduk Indonesia yang berusia 30 tahun, terjerat kasus narkoba.

Dengan semakin meningkatnya penggunaan narkoba merupakan sinyal bahaya bagi generasi muda bangsa kita. Seperti yang kita ketahui penggunaan narkoba di usia muda merupakan masalah kesehatan masyarakat. Kristen \& Eric dalam penelitiannya mengungkapkan (2007: $\mathrm{hlm}$. 318) pemuda yang menggunakan obat-obatan terlarang, termasuk alkohol dan tembakau, berada pada risiko yang lebih tinggi untuk hasil yang negatif, termasuk prestasi akademik yang miskin dan peningkatan drop-out sekolah (Ellickson, Bui, \& Bell, 1998; Ellickson, Tucker, \& Klein, 2003; Windle \& Wiesner, 2004), inisiasi seksual dini (Mott, Fondell, Hu, Kowaleski-Jones, \& Menaghan, 1996; Pusat Nasional Penambahan dan Penyalahgunaan Zat, 1999), perbuatan kekerasan (US Department of Health and Human Services, 2001 ), dan penyalahgunaan zat kemudian dan ketergantungan (Anthony \& Petronis, 1995; Gil, Wagner, \& Tubman, 2004; Hawkins et al, 1997). Selain itu Collingwood et.al (2000: hlm. 436) mengatakan Banyak faktor risiko yang telah ditetapkan untuk perilaku penyalahgunaan zat di kalangan pemuda termasuk rendah diri, depresi, kurangnya kontrol diri, prestasi sekolah yang buruk, orangtua miskin dan hubungan rekan, dan gaya hidup negatif (kebiasaan makan yang buruk, stres, dan tidak aktif) hingga kematian.

Di Amerika telah berbagai upaya untuk menekan penyalahgunaan narkoba. Salah satunya program pencegahan penggunaan narkoba berbasis sekolah yang telah menjadi bagian integral dari kampanye antinarkoba AS selama dua dekade terakhir (Glynn dalam Ennet, 1994: hlm. 1394). Cara tersebut diyakini oleh Joel (2001: hlm. 84) yang mengatakan "School-based programs have constituted the bulk of prevention efforts in the past and are likely to do so in the foreseeable future." Too Good for Drugs (TGFD) adalah program intervensi obat berbasis sekolah yang dirancang untuk mengurangi penggunaan alcohol, tobacco, and other drugs (ATOD) kalangan anak-anak dan remaja dan untuk mengurangi faktor risiko dan meningkatkan faktor protektif berkaitan dengan penggunaan ATOD (Bruce et.al, 2013: $\mathrm{hlm}$. 279). Penelitian telah menunjukkan bahwa kurikulum pencegahan narkoba dapat efektif dalam menekan penggunaan narkoba saat ini atau masa depan di kalangan siswa berisiko karena faktor ekonomi atau lainnya (misalnya, Botvin, Griffin, Diaz, \& Ifill-Williams, 2001; Eisen, Zellman, Massett, \& Murray, 2002; Ellickson, McCaffrey, Ghosh-Dastidar, \& Longshore, 2003; Longshore, Ellickson, McCaffrey, \& St. Clair, 2007; Perry, Williams, Komro, VeblenMortenson, Stigler, Munson, et al, 2002; Bruce et.al, 2013: hlm. 278) tetapi belum ada penelitian mengenai kurikulum pencegahan narkoba di Indonesia dan dalam pendidikan jasmani di sekolah. 
Tujuan dari penelitian ini adalah untuk melihat efektifitas kurikulum pencegahan narkoba dalam pendidikan jasmani di sekolah tanpa menurunkan kemampuan gerak siswa. Pendidikan jasmani dipercaya dapat menjadi solusi penggunaan narkoba di Indonesia karena program pendidikan jasmani telah lama diakui sebagai komponen kunci dalam upaya promosi kesehatan sekolah. Wuest \& Lombardo dalam Brich \& Kane (1999: hlm. 57) menyebut promosi gaya hidup sehat merupakan "warisan penting" pendidikan jasmani sekolah. Pate, Corbin, Simons-Morton, \& Ross dalam Brich \& Kane (1999: hlm. 57).

\section{Metode Penelitian}

Metode penelitian yang digunakan dalam penelitian ini adalah metode penelitian eksperimen. Metode penelitian eksperimen dapat diartikan sebagai salah satu metode penelitian yang dapat digunakan untuk mencari sebuah pengaruh perlakuan tertentu terhadap yang lain, dengan kondisi yang terkendalikan".

\section{Desain Penelitian}

Dalam penelitian ini peneliti menggunakan desain The-Static Group Pretest-Posttest Design menurut Frankel (2012, hlm. 270).

$$
\begin{array}{llll}
\text { Treatment group } & \mathrm{O} & \mathrm{X} & \mathrm{O} \\
\cline { 2 - 4 } & & & \\
\text { Control Group } & \mathrm{O} & & \mathrm{O}
\end{array}
$$

Gambar 1. Desain Penelitian (Sumber Frankel 2012:270)

Keterangan :

0 : Pretest dan Posttest (dengan menggunakan angket perilaku pencegahan penyalahgunaan narkoba)

\section{$X$ : Treatment}

Sampel penelitian adalah siswa kelas XI A SMA Harapan Umat Karawang yang berjumlah 20 orang sedangkan yang menjadi sampel kontrolnya adalah siswa dari tingkatan kelas yang sama yaitu siswa kelas XI B SMA Harapan Umat Karawang yang berjumlah 40 orang.

Instrumen yang digunakan untuk mengukur pengaruh kurikulum pencegahan narkoba adalah dengan cara memberikan angket. Angket merupakan suatu teknik untuk pengumpulan data yang dilakukan dengan cara memberi seperangkat pertanyaan atau pernyataan tertulis kepada responden untuk dijawabnya. Kriteria pemberian skor untuk setiap jawaban butir pernyataan sesuai dengan positif atau negatifnya pernyataan tersebut. Untuk lebih jelasnya dapat dilihat pada table 3.1

Tabel 1.

\begin{tabular}{|r|l|c|c|}
\hline \multirow{2}{*}{ No } & \multirow{2}{*}{ Alternatif Jawaban } & \multicolumn{2}{|c|}{ Skor Alternatif Jawaban } \\
\cline { 3 - 4 } & & Positif & Negatif \\
\hline 1. & Sangat Setuju & 5 & 1 \\
\hline 2. & Setuju & 4 & 2 \\
\hline 3. & Ragu-ragu & 3 & 3 \\
\hline 4. & Tidak Setuju & 2 & 4 \\
\hline 5. & Sangat Tidak Setuju & 1 & 5 \\
\hline
\end{tabular}

Instrumen angket yang digunakan menggunakan instrument yang sudah ada atau dari penelitian terdahulu. Instrument angket pencegahan penyalahgunaan narkoba menggunakan 
instrument dari Istiadi (2012). Adapun untuk mengukur kebugaran peneliti menggunakan FITNESSGRAM Test.

\section{Hasil dan Pembahasan}

Dalam penletian yang telah dilakukan dapat didiskusikan bahwa implementasai pembelajaran perilaku pencegahan penyalahgunaan Narkoba dalam pendidikan jasmani memeberikan pengaruh yang signifikan kepada peserta didik. Hal ini membuktikan bahwa peran pembelajaran pencegahan narkoba dalam kurikulum pendidikan jasmani mampu memeberikan pengaruh yang signifikan terhadap siswa dalam perilaku pencegahan narkoba.

\section{Daftar Pustaka}

Abduljabar, B. Pengertian Pendidikan Jasmani. [Online]. Diakses Tanggal 17 Agustus 2015: http://file.upi.edu/Direktori/FPOK/JUR._PEND._OLAHRAGA/196509091991021 -

BAMBANG_ABDULJABAR/Pengertian_Penjas.pdf.

Agung. (2013). Tiga Langkah Membangun Remaja Bebas Narkoba. Laporan penelitian untuk BNN Kabupaten Pati. Jakarta

Botvin, G. J., Griffin, K. W., Diaz, T., \& Ifill-Williams, M. 2001. Drug abuse prevention among minority adolescents: Posttest and one-year follow-up of a school-based preventive intervention. Prevention Science, 2(1), 1-13.

Badan Narkotika Provinsi DKI Jakarta (2009). Modul Pencegahan Penyalahgunaan Narkoba. Jakarta: disusun oleh Tim Bagian Prevensi BNP DKI.

Bruce, $\mathrm{H}$ et al. 2013. Randomized Controlled Evaluation Of The Too Good For Drugs Prevention Program: Impact On Adolescents At Different Risk Levels For Drug Use. J. Drug Education, Vol. 43(3) 277-300

Collingwood, T et al. 1991. Physical Training As A Substance Abuse Prevention Intervention For Youth. J. Drug Education, Vol. 30(4) 435-451.Darmadi, Hamid. (2011). Metode Penelitian Pendidikan. Bandung : Penerbit Alfa Beta.

Eisen, M., Zellman, G. L., Massett, H. A., \& Murray, D. M. 2002. Evaluating the Lions-Quest "skills for adolescence" drug education program: First-year behavior outcomes. Addictive Behaviors, 27, 619-632.

Ellickson, P. L., McCaffrey, D. F., Ghosh-Dastidar, B., \& Longshore, D. L. 2003. New inroads in preventing adolescent drug use: Results from a large-scale trial of Project ALERT in middle schools. American Journal of Public Health, 93, 1830-1836.

Ennet. $S$ et al. 1994. How Effective Is Drug Abuse Resistance Education? A Meta-Analysis Of Project Dare Outcome Evaluations. American Journal of Public Health, September 1994, Vol. 84, No. 9. 